\section{Impact of Family Functioning, Family Violence and Other Factors on Juvenile Delinquency}

Januka Neupane ${ }^{*}$ and Pravat Uprety ${ }^{2}$

Submitted: 24 September 2021; Accepted: 23 November 2021

Published online: 5 December 202I

DOI: https://doi.org//0.3 I26/njs.v5il.4I 23 I

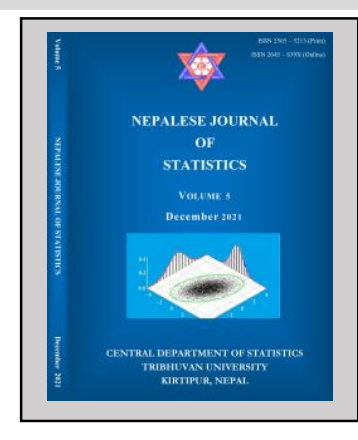

\title{
ABSTRACT
}

Background: Juvenile delinquency is the act of participating in unlawful behavior as minors or individuals younger than the age of majority. Nepal shows an increasing trend of violent crimes committed by a juvenile.

Objective: To examine the impact of family functioning, family violence, and other family factors on juvenile delinquency.

Materials and Methods: The study is a case-control study based on primary data collection of 354 respondents which include equal number of juvenile delinquents as cases taken from juvenile correction homes and school students as controls who have never been convicted for any act of juvenile delinquency. Data was collected through the convenience sampling method. Structured questionnaire was used to collect data on demographic, socioeconomic, individual and family factors. Bivariate and logistic regression analysis were performed to determine which factor act as a risk or protective factor for juvenile delinquency.

Results: From bivariate analysis, family factors such as family functioning, parental monitoring, parental involvement, parental supervision, and parental attachment were found higher in controls than cases. However, family violence was found higher in cases than control group. Further, from fitted logistic regression child age, aggressive behavior, family structure, family financial condition, punitive parenthood, mother education level, and parental attachment were found significant factors impacting on juvenile delinquency.

Conclusion: This study revealed that age, aggressive behavior, family structure, and family financial condition are the risk factors for juvenile delinquency. Further, mother education, punitive parenthood, and parental attachment are found protective factors for juvenile delinquency.

Keywords: Family functioning, family violence, juvenile delinquency, logistic regression, parental attachment, parental involvement, parental monitoring, parental supervision.

Address correspondence to the author: Central Department of Statistics, Tribhuvan University, Kirtipur, Nepal ${ }^{1,2}$. E-mail: janukaneupane872@gmail.com ${ }^{\text {** }}$ (Corresponding author email); pravatup@gmail.com² 


\section{INTRODUCTION}

Juvenile delinquency is one of the burning issues all over the world. The understanding of "Juvenile delinquency" is that the offences committed by juveniles, whose age conforms to the age group specified by the law as a juvenile (Siegal \& Welsh, 2016). When these children come into the contact with the justice system as a result of being suspected or accused of committing an offence they will be known as children in conflict with the law, which causes serious problems in society (Goldberg, 2002). The Act Relating to Children (2018) define the term "Children in conflict with law" means children less than 18 years of age, accused of committing an offence, and this term also includes the children convicted by the Juvenile Court for committing an offence. In Nepal, there were nearly 9 million young people aged 10-24 years in 201 I, which is one third of the total population. Similarly, adolescents, the young population of $10-19$ years, make up $24.2 \%$ of the population and youth of the age group (I5-24) years make up almost $20 \%$ of the total population of Nepal (CBS, 2014). The crime rate in recent years has surged, not only in Nepal but the scenario is much graver in the developed countries. Nepal Adolescent and Youth Survey 2010/201I, reported that about 3\% of young people age 10-24 year had involved in harming or destroying others' property intentionally, followed by unsociable behavior like attacking someone with an intention of injuring him/her (I\%) (MoPH, 20I2). Similarly, National Child Right Council (2019), mention that the juvenile cases in 2018 was 382. And the number of such children increased to 821 in 2019, including 23 girls, were sent to juvenile correction centers throughout the country in 2018-19. Among them, $73 \%$ of children were in the age group of $16-18,23 \%$ in the age group of 14-15, and $3 \%$ were below the age of 14 . They were found guilty of 15 types of offenses including rape, murder, drug smuggling, and theft etc.

The family is the primary unit in which children learn the value and attitudes that guide their actions throughout their lives. The family role is also important in developing basic social and religious values among adolescents and youth. Every problem related to children is directly or indirectly linked with a family atmosphere. Family distribution or change can have a long-lasting impact on children. Effective parenting can help neutralize the effect. Lack of Parental supervision, absence of parental involvement, and Parent's marital relation in a family can lead to the development of criminality in the child (Wright \& Wright, 1994). Unstable family income, broken home, family mobility, mental health of the parent, young mother, number of children in the family, single parent family, parental past are the main risk factors associated with family characteristics (Savignac, 2009). There are lots of factors that encourage children to be delinquent. One of the important risk factors on juvenile delinquency is the individual risk factor which includes emotional factors such as aggressive behavior, low educational aspirations, low educational attainment are the most apparent and best predictor of later delinquency (Farrington, Loeber, \& Van Kammen, 1990: Bartol \& Bartol, 2009: Kirk \& Sampson, 2013). Delinquent or aggressive behavior of Nepalese adolescents was associated with use of tobacco, alcohol or other substance (Karki, Laukkanen, Länsimies, Tuomainen \& Pietilä, 2019). 
Nepal Adolescent and Youth Survey 2010/20II, reported that 13\% of the young people aged 10-24 years had used tobacco, $18 \%$ had consumed alcohol, and $6 \%$ had misused illicit drugs (MoHP, 2012). Witnessing and experiencing violence in the home is an important risk factor for aggressiveness and delinquency in young people (Saviangac, 2009). According to the results of the National Longitudinal Survey of Children and Youth (NLSCY), children aged 6 to II who have witnessed violence in the home were twice ( 2.2 times) as likely to behave aggressively as children who had never witnessed violence (Hotton, 2003). Other studies have also shown that violence experienced at an early age is a factor associated with running away and early departure from the family home, which strongly increases an adolescent's risk of becoming the victim or the perpetrator of various forms of delinquency related to homelessness (Savignac, 2009). Similarly, Nepal Adolescent and Youth Survey 2010/20II also found that $24 \%$ of Adolescent and Young faced physical violence from any one of their family members and $8 \%$ were beaten by someone outside the family during the last one year (MoPH, 20I2). McCord found that children who are brought up in families where they are closely supervised and have interaction are less likely to turn into criminals as adults. Parental monitoring, supervision, involvement, and attachment appear to be especially important in the case of an adolescent participating in crime and delinquency (McCord, 1991). The study shows that parental monitoring has been associated with less delinquent behavior (Thornberry \& Krohn, 2003) and is a protective factor for adolescents against delinquency. Children who are strongly attached to their parents during childhood and adolescence are less likely to engage in delinquent activities (Smith, Weiher \& Van Kammen, 1993).

Children in Nepal are regarded as a "gift of the god" and we call them a pillar of the nation. The child is involved in criminal activity is the most sensitive and to be accounted for issue in the present time. The children are psychologically and physically immature. They can be diverted easily by small things and events. Taking on this term is strongly associated with the family. The family environment is the foremost thing that determines either the child being involved in a delinquent activity or not. In Nepal, the problem of juvenile delinquency has received little attention from researchers, administrators, and social workers. Therefore, an investigation in this field is to find out family factors so that there would a greater understanding of the issue and measures that could be taken to prevent and control this growing issue. The major objective of the current study is to assess the impact of family functioning, family violence and other family-related factors on juvenile delinquency. Moreover, the paper is focused on identifying the impact of socio-economic and demographic factors associated with juvenile delinquency through the use of the appropriate statistical model.

\section{MATERIALS AND METHODS}

\section{Data and study area}

The current study was a case-control study entirely based on primary data collection. This study was conducted in two districts Bhaktapur and Rupandehi of Nepal. Children from selected districts Children Correction Home who were convicted for acts of juvenile delinquency and found guilty, who assented to take part in the study were included as cases and children from respected 
districts studying in $8^{\text {th }}-12^{\text {th }}$ standard in selected government schools who were never convicted for any acts of juvenile delinquency were selected as control which is similar to that of cases in gender, and approximately similar age group. An equal number of cases and control were recruited. The sample size was limited by the number of delinquent children in Children Correction Home. The judgmental sampling technique was used to select Correction homes/schools one from within Kathmandu valley (hill) that is located in Bhaktapur and another from Terai (Rupandehi) to cover the diversified group and the convenience sampling technique (whoever available during the survey period) was used to select the respondents from selected correction homes/ schools. Considering $95 \%$ confidence level, $5 \%$ margin of the error and $50 \%$ population proportion, 385 sample size was determined and which is equally divided into Juvenile delinquent (treatment and Non-delinquent control, that is 193 from each group). But during the survey period, the pandemic Covid-19 was happening so that data could be collected only from 354 (See Annex). The questionnaire was developed in English first and back to back translation was done in Nepali language, without changing its essence.

\section{Variables}

The response variable of this study is dichotomous i.e. either the respondents were juvenile delinquent or non-delinquent. By reviewing the various relevant literature different continuous and categorical variables are selected as explanatory variables. Further, explanatory variables were classified into demographic, socioeconomic, individual, and family factors. Sociodemographic variables include age, gender, caste/ethnicity, occupation of respondent, education level, birth order, number of siblings, family size, father age, maternal age, father education level, mother education level, marital number of father and mother, marital order of father and mother, family type, family structure, punitive parenthood, parents smoking habits, parents' alcohol consuming habits, and family relationship with neighbor. Socio-economic variables include the father's occupation, mother's occupation, and family financial condition. Individual variables include education performance, smoking status, alcohol-consuming status and emotional behaviors of the respondent.

Family factors include family functioning, family violence, parental supervision, parental monitoring, parental involvement and parental attachment which are measure using a 5-point Likert-type scale that ranged from I (strongly unsatisfied) to 5 (strongly satisfied). For measuring the family function, Family Adaptability and Cohesion Evaluation Scales (FACES III) developed by Olson, Russell, \& Sprenkle (1983) was used. Further, the family functioning is divided into twodimension, Family Cohesion, and Family Adaptability. Family Cohesion measures how the family member feels closer to each other and Family Adaptability measure the rule changes in their family. It was assessed by 20 items questionnaire. To measure the family violence different questions related to family violence were asked to the respondent and Six items with 5 points Likert scale were selected for the measurement of family violence that ranges from I(strongly unsatisfied) to 5 (strongly satisfied). For measuring parental supervision, 10 items, a 5-point Likert scale developed by Gottfredson and Gottfredson (1999) was. Parental Monitoring was assessed by partially 
adopting the parental monitoring questionnaire developed by Stattin and Kerr (2000) which is measured by using 6 items 5 point-Likert scales self-reported questionnaire. Similarly, to measure parental involvement 8-item self-reported questionnaire about parental involvement were used, questions ask if the respondent has done the following things with their mother-father: gone shopping, played a sport, gone to a religious service, go to a movie/visited, play, and worked on a project for school, etc. At last, 14 items with 5 points Likert scale self-reported questionnaire was used to measure the parental attachment with the respondent. The reliability of these family factors was measure through Cronbach's alpha. Cronbach's alpha for family functioning, family violence, parental supervision, parental monitoring, parental involvement and parental attachment is found $0.719,0.702,0.754,0.633,0.792$, and 0.907 respectively. The acceptable value for Cronbach's alpha is greater than 0.6 (George and Mallery, 2003). This can be considered as reasonably high. Hence, the scale is reliable.

\section{Data analysis}

The study was done to obtain both descriptive as well as inferential statistics. Statistical methods Chi-square, t-test, and logistic regression, were performed to identify significant factors that impact juvenile delinquency. The binary logistic model was developed to establish the relationship between juvenile delinquency and significant factors affecting it. Logistic regression analysis studies the association between a categorical dependent variable and a set of independent (explanatory) variables. It is used to analyze the relationship between a categorical dependent variable and a continuous or categorical independent variable. Generally, the dependent variable is dichotomous.

\section{Let $Y_{i}=\quad \mathrm{I}$, Juvenile delinquent \\ 0 , Non- delinquent}

In logistic regression, the conditional mean of $Y$ for given values of $x$ is denoted as: $\Pi(x)=E(y / x)$ The specific form of the logistic model for the number of explanatory variables $\left(X_{i}\right)$ and the model for $\pi_{i}=P\left(Y_{i}=1\right)$ and $1-\pi_{i}=p\left(Y_{i}=0\right)$ for $\mathrm{t}$ explanatory variables $X_{1}, X_{2}, X_{3} \ldots \ldots \ldots, X_{t}$ is given as;

and

$$
\Pi_{\mathrm{i}}(\mathrm{x})=\frac{e^{\beta_{0}+\beta_{1} x_{1}+\beta_{2} x_{2}+\cdots \ldots \ldots .+\beta_{t} x_{t}}}{1+e^{\beta_{0}+\beta_{1} x_{1}+\beta_{2} x_{2}+\cdots \ldots \ldots .+\beta_{t} x_{t}}}
$$

$$
1-\Pi_{\mathrm{i}}(\mathrm{x})=\frac{e^{-\left(\beta_{0}+\beta_{1} x_{1}+\beta_{2} x_{2}+\cdots \ldots \ldots+\beta_{t} x_{t}\right)}}{1+e^{-\left(\beta_{0}+\beta_{1} x_{1}+\beta_{2} x_{2}+\cdots \ldots \ldots .+\beta_{t} x_{t}\right)}}
$$

The logit transformation in terms of $\Pi(x)$ is as:

$$
\begin{gathered}
g(x)=\operatorname{In}\left(\frac{\pi_{i}(x)}{1-\pi_{i}(x)}\right) \\
g(X)=\beta_{0}+\beta_{1} \mathrm{x}_{1}+\beta_{2} \mathrm{x}_{2}+\cdots \ldots \ldots \ldots+\beta_{t} \mathrm{x}_{t}
\end{gathered}
$$


where $\Pi(x)$ is the probability that the event $y$ occurs $\Pi(Y=I) ; g(x)$ is the logit transformation and also called logit (logistic) model; $\frac{\pi_{i}(x)}{1-\pi_{i}(x)}$ is the odds ratio; $\operatorname{In}\left(\frac{\pi_{i}(x)}{1-\pi_{i}(x)}\right)$ Is the log odds ratio or logit.

\section{Model adequacy tests}

The Hosmer-Lemeshow (HL test) is a goodness of fit test for logistic regression, especially for risk prediction models. Specifically, the HL test calculates if the observed event rates match the expected event rates in population subgroups and compute a chi-square from observed and expected frequencies. In this test $\mathrm{p}>0.05$ indicate that there is enough evidence to say the model fit quite well. Pseudo $R^{2}$ measures the amount of variation in the dependent variable explained by the independent variable for this Cox \& Snell, and Nagelkerke were used. The omnibus test of the model coefficient is used to check that the model with the explanatory variable is an improvement over the baseline model. The collinearity between the explanatory variables is ensured by computing the Variance Inflation Factor (VIF). To test the scale of reliability of the Likert scale questionnaire Cronbach Alpha is used.

\section{RESULTS}

The study consists of 354 children, among them 177 (50\%) of them were juvenile delinquent and $177(50 \%)$ were non-delinquent children. Among all the respondents, 3।4(83.I \%) respondents are male and 40 ( $11.3 \%)$ are female. These respondents were between the age of 13 years and 21 years and the mean age is 16.43 years and the median age is 16 years. Among them, $99(28.0 \%)$ respondents are below 16 years, 255(72.0\%) are above 16 years. This study consists of $124(35.0 \%)$ of the respondents are Brahmin/ Chhetri, 133(37.6\%) are Janajati, 38(10.7\%) are Madhesi, and 59 (16.7\%) are Dalit. Similarly, $4.2 \%$ of respondents studying at the primary level, $18.4 \%$ of respondents studying lower secondary level, $53.1 \%$ of respondents were in the secondary level, $22.9 \%$ of respondents were in the Intermediate level, and only $1.4 \%$ of respondents in the bachelor level. Among total respondents, I2I (34.2\%) of respondents are born as a first child of their parents, $107(30.2 \%)$ of them are the last child, $14(4.0 \%)$ of them were born as a single child, and $112(31.6 \%)$ of the respondent were other birth order of their parents. Out of 354 respondents, $34 \mathrm{I}(96.3 \%)$ of respondents were unmarried and 13(3.7\%) were married. The average family size of the respondent is approximately 6 and they have a minimum of 2 and a maximum of 21 family members. The respondent has an average of 3 siblings and they have no to 19 siblings. Similarly, the respondent's fathers have got a minimum of I to 4 marriages while the mothers have got I to 2 marriages.

Among 177 delinquent respondents, 91(5I.4\%) respondents were refuse to give the information regarding their charges, and the majority of the respondent $38(21.8 \%)$ of delinquent charges with rape and attempt to rape cases, 17(9.6\%) of the respondent charges for Thief, 15(8.5\%) were charges for drugs case, 13(7.3 \%) charges for murdered and only one boy for an attempt to murder, and one boy charges for ford, kidnapping and child marriage.). Data also reveals that among non-delinquent respondents I76(99.4\%) were the student and only I $(0.6 \%)$ were an 
employee. Whereas in the delinquent group, 292(65.5\%) were the student and 62(34.5\%) were an employee. And it was also found that they were engaged in a job like a waiter at a hotel, Co-driver who worked at the gold shop, a barber, wall painting, Welding, wiring, Street chocolate seller, street water seller, car washing, paper distribution, etc. Bivariate analysis of family factors was done and the result is shown in annex. From the bivariate analysis, independent variables such as family structure, respondent's occupation, father age, father's educational level, mother's educational level, father occupation, respondent smoking status, respondent alcohol-consuming status, parent's smoking status, marital order of father, family relationship with the neighbor, aggressive behavior of the respondent, number of siblings, punitive parents are found to be significantly associated with juvenile delinquency.

Among family factors, present study found that Family Functioning, Family Violence, Parental Attachment, Parental Monitoring, Parental Involvement, and Parental supervision have a statistically significant difference between the mean of delinquent and non-delinquent groups at a $5 \%$ level of significance. In present study family functioning was measured by two dimension i.e. family adaptability and family cohesion. Family adaptability and family cohesion observed higher in nondelinquent group than delinquent group. Similarly, family violence is found higher in delinquent group than non-delinquent group. Also, it is observed that higher degree of children attachment with their parents (parental attachment), parental monitoring, involvement of parents in children work or activity (parental involvement), and parental supervision are found in non-delinquent group than delinquent group. Out of the significant factors from bivariate analysis, two of them, namely respondent occupation, family relationship with neighbors had very little data in one of the four entries in the $2 \times 2$ table. So the result of the odd's ratio may affect the entire analysis hence these variables are not included in logistic regression and some of the categories in few categorical independent variables were merged due to few numbers of the respondent. Results are shown in Table 2.

Those children whose age is less than 16 years have $(1-0.089) * 100 \%=91.1 \%$ (95\% C.I: 0.029 to $0.27 \mathrm{I}$ ) less chance to be delinquent as compare to the children whose age is greater than 16 years. The children with aggressive behavior have 5.388 times more likely ( $95 \%$ C.I: 1.70 I to 17.07I) to have the risk of delinquency as compared to the children who do not have aggressive behavior. Family structure is found strongly significant at a $5 \%$ level of significance. The children having other than Biological parent family structure (which include at least one step-parent family/single-parent family or no parent family) have II.169 times more likely ( $95 \%$ C.I: 1.09 I to II 4.3 I2) to have the risk of delinquency as compared to the children having Biological parents. The Children having a low family financial condition is 5.219 times more likely (95\% C.I: 1.762, I5.44I) to be delinquent as compare to the respondent having the medium or high family financial condition.

Mother's educational level, punitive parenthood, and parental attachment are found significant in fitted multiple logistic regression for the outcome variable. While fitting multiple 
logistic models, the variable mother's educational level has only one category is found significant. The result (Table 2) showing that the higher the educational level of the mother lowers the risk of delinquency of their children. Those children whose mothers studied up to SLC are $77.3 \%$ (95\% C.I: 0.073 to 0.705 ) fewer chances to be delinquent as compare to the illiterate mother. Similarly, the odds of children having the risk of juvenile delinquency is $78.3 \%$ less chance to be delinquent children whose parents give punishment for did something wrong as compare to the children whose parents didn't give punishment.

Table 2. Odds ratio for logistic regression model of juvenile delinquency.

\begin{tabular}{|c|c|c|c|c|c|c|c|}
\hline \multirow{2}{*}{ Variables } & \multirow{2}{*}{ Categories } & \multirow{2}{*}{ B } & \multirow{2}{*}{ S. E. } & \multirow{2}{*}{ P-value } & \multirow{2}{*}{$\operatorname{Exp}(B)$} & \multicolumn{2}{|c|}{$95 \%$ C.I. for $\operatorname{Exp}(B)$} \\
\hline & & & & & & Lower & Upper \\
\hline $\begin{array}{l}\text { Respondent } \\
\text { age }\end{array}$ & $\begin{array}{l}\text { Below } 16 \text { years } \\
\text { Above } 16 \text { years } \AA\end{array}$ & 2.423 & 0.569 & 0.00 & 0.089 & 0.029 & 0.271 \\
\hline $\begin{array}{l}\text { Family } \\
\text { Structure }\end{array}$ & $\begin{array}{l}\text { Biological Parent }{ }^{\circledR} \\
\text { Other parents (step } \\
\text { parent/single } \\
\text { parent/ no parent } \\
\text { family) }\end{array}$ & 2.413 & 1.187 & 0.042 & 11.169 & 1.091 & 114.312 \\
\hline $\begin{array}{l}\text { The financial } \\
\text { condition of } \\
\text { the family }\end{array}$ & $\begin{array}{c}\text { Low } \\
\text { Medium or high }{ }^{\circledR}\end{array}$ & 1.652 & 0.553 & 0.003 & 5.219 & 1.764 & $|5.44|$ \\
\hline $\begin{array}{l}\text { Aggressive } \\
\text { Behavior of } \\
\text { children }\end{array}$ & $\begin{array}{l}\text { Yes } \\
\mathrm{No} 尺\end{array}$ & 1.684 & 0.588 & 0.004 & 5.388 & 1.701 & |7.07| \\
\hline \multirow{3}{*}{$\begin{array}{l}\text { Mother } \\
\text { education } \\
\text { level }\end{array}$} & Illiterate $®$ & & & 0.065 & & & \\
\hline & Up to SLC & $\begin{array}{l}-1.482 \\
2986\end{array}$ & 0.578 & $\begin{array}{l}0.01 \\
0.159\end{array}$ & 0.227 & $\begin{array}{l}0.073 \\
000 !\end{array}$ & $\begin{array}{l}0.705 \\
3232\end{array}$ \\
\hline & Bachelor and above & -0.435 & 1.373 & 0.751 & 0.647 & 0.044 & 9.539 \\
\hline $\begin{array}{l}\text { Punitive } \\
\text { parenthood }\end{array}$ & $\begin{array}{l}\text { Yes } \\
\mathrm{No} \circledast\end{array}$ & -1.529 & 0.589 & 0.009 & 0.217 & 0.068 & 0.688 \\
\hline $\begin{array}{l}\text { Parental } \\
\text { Attachment }\end{array}$ & & -2.545 & 0.575 & 0.00 & 0.078 & 0.025 & 0.242 \\
\hline Constant & & 14.903 & 3.170 & 0.00 & - & & \\
\hline
\end{tabular}

where $\AA=$ Reference Category.

The odd of the children being delinquent when the parental attachment is increased by one unit is $92.2 \%$ ( $95 \%$ C.I: 0.025 to 0.242 ) less chance to be delinquent children. The overall goodness 
of fit of the fitted logistic model is assessed by $R^{2}$ statistics and Hosmer Lemeshow test. The predictive of the fitted model is $51.3 \%$ assessed through Cox \& Snell $R^{2}$ (Pseudo $R^{2}$ ). This shows that $51.3 \%$ of the variation in the dependent variable is explained by the fitted logistic model. By the Hosmer Lemeshow, the value of chi-square is 9.136 with 8 degrees of freedom and the $p$-value is greater than 0.05 which implies that there is no significant difference between observed and predicted values indicating that the goodness of fit of the model has not been violated. By the Omnibus Test, the $\mathrm{p}$-value is less than $<0.05$ indicates the overall model coefficients are significant in the model. It can also be concluded that the new model is explaining more of the variance in the outcome and is an improved model $(P<0.05)$. The VIFs of all covariates were found to be less than 1.16 , which indicates that there is no multicollinearity between the covariates.

\section{DISCUSSION}

Juvenile delinquency is an anti-social or illegal activity by kids in their teens or pre-teen ages. It has been increasing rapidly in Nepal and hence this is a burning issue of our country in today's context. The present study was initiated to explore the family factors impacting juvenile delinquency. This case-control study on juvenile delinquency identify children age, aggressive behavior of children, family structure, family financial condition as a significant independent risk factor and punitive parenthood, mother education level, and parental attachment are the protective factors on juvenile delinquency. The limitation of the study is all the biases inherent to the case-control design, the most important of which is recall bias (Gordis, 2009). In the present study, among 177 cases, 157 (88.7\%) of the respondent are male and only 20 (II.3\%) female shows that the number of children involves in criminal activity is higher in males than females. The study conducted in $198 \mathrm{I}$ by Hindelang et al. found that the boy commits delinquent acts more frequently and seriously than girls. A previous study has identified advanced paternal age, paternal smoking, maternal employment, and single parenthood as significant independent risk factors (Rathinabalan, 2017). On the other hand, punitive parenthood has a protective effect due to the setting of hypothesis, that assumed punitive behavior as part of positive parental supervision and goal setting which led to the punishment, and the result of this study is consistent with the present study. The result of the present study is consistent with the study of Laursen (2005) and found that twobiological-parent families compared to other family types are a protective factor in juvenile delinquency. The present study found that the children having other than Biological parent family structure (which include at least one step-parent family/single-parent family or no parent family) have 11.169 times the high risk of delinquency as compared to the children having biological parents. Aggressive behavior during childhood is the most important risk factor for delinquency (Bartol \& Bartol, 2009: Farrington, Loeber, \& Van Kammen, 1990). The present study also found that the children having aggressive behavior is 5.388 times higher risk of delinquency than those children who don't have aggressive behavior. In addition, several past studies stated that an increase in parental supervision, parental monitoring, parental involvement, parental attachment, less family violence and can reduce the likelihood of delinquency (McCord, 1991: Thornberry \& Krohn, 2003: Smith, Weiher \& Van Kammen, 1993: Wright \& Wright, 1994). In a present study among different family factors included in the study, only parental attachment is found significant this is due to the 

reason that most of the perception variable and their family environment is found to be similar in both case and control group.

The risk factor will increase the likelihood of children become delinquent and several studies on juvenile delinquency were noted that multiplicative effect of several risk factors also presented. Research conducted by Herrenkohl and colleagues (2000) report that a 10-year-old exposed to six or more risk factors is 10 times as likely to commit a violent act by age 18 as a 10 -year-old exposed to only one risk factor. Therefore, it is important to identify the root cause of delinquency. Hence, the present study identified risk and protective factors within the family environment.

\section{CONCLUSION}

The objective of this study is to examine the impact of family functioning, family violence and other family factors on juvenile delinquency in Nepal. The objective has been achieved, as the study explores 'children age', 'aggressive behavior of children', 'family structure', 'family financial condition' 'punitive parenthood', 'mother education level', and 'parental attachment' as factors that impact on juvenile delinquency. The age of children is found significant factor impacting juvenile delinquency, as this study found that children under 16 years are less likely of being delinquent as compare to children above 16 years. Secondly, aggressive behavior of children is another individual factor that plays a pivotal role in juvenile delinquency as this study found the aggressive behavior of children will increase the risk of delinquency. Family structure is also found significant variable as the study indicate that children having other parents (single parent/ step-parent) family structure are more likely to be delinquent as compare to the children having biological parents. The present study pointed those children with low family financial conditions are more likely to be delinquent than children having medium or high family financial condition. Present study also found that increase punitive parenthood decrease the likelihood of delinquency. Further, it is found that the higher the education level of the mother lower the delinquency. The present study also found that the increase in parental attachment leads to a decrease in the risk of juvenile delinquency.

\section{CONFLICT OF INTEREST}

The authors declared that there is no conflict of interest.

\section{ACKNOWLEDGEMENTS}

Authors would like to express sincere gratitude to Prof. Dr. Srijan Lal Shrestha, Prof. Dr. Gauri Shrestha, Prof. Dr. Shankar Prasad Khanal, Prof. Dr. Ram Prasad Khatiwada and Mr. Nagendra Amatya for insightful comments and encouragement to complete this paper. Also, authors would like to acknowledge University Grants Commission, Sanothimi for providing financial support for the study.

\section{REFERENCES}

Bartol, C. R., \& Bartol, A. M. (2009). Juvenile delinquency and antisocial behaviour: A developmental perspective. Pearson Prentice Hall. 
Central Bureau of Statistics (20I4). Population Monograph of Nepal. Volume I. Government of Nepal, National Planning Commission Secretariat, Kathmandu, Nepal.

Farrington, D. P., Loeber, R., \& Van Kammen, W. B. (1990). Long-term criminal outcomes of hyperactivity-impulsivity-attention deficit and conduct problems in childhood. Cambridge University Press.

George, D., \& Mallery, P. (2003). SPSS for Windows step by step: A simple guide and reference. (4th Ed.). Boston: Allyn \& Bacon.

Goldberg, E. (2002). The executive brain: Frontal lobes and the civilized mind. Oxford University Press, USA.

Gordis, L. (2009). Case-control studies and other study designs. Epidemiology, 4, 177-200.

Gottfredson, G. D., \& Gottfredson, D. C. (1999). Development and applications of theoretical measures for evaluating drug and delinquency prevention programs: Technical manual for research editions of What About You (WAY). Gottfredson Associates.

Herrenkohl, T. I., Maguin, E., Hill, K. G., Hawkins, J. D., Abbott, R. D., \& Catalano, R. F. (2000). Developmental risk factors for youth violence. Journal of adolescent health, 26(3), 176186.

Hindelang, M. J., Hirschi, T., \& Weis, J. G. (1981). Measuring delinquency. Beverly Hills: Sage Publications.

Hotton, T. (2003). Childhood aggression and exposure to violence in the home. Ottawa: Statistics Canada.

Karki, S., Laukkanen.E., Länsimies .H., Tuomainen. T.P., \& Pietilä. A.M. (2019). Substance use and associated emotional and behavioural problems in Nepalese adolescents. Journal of Substance Use, 24(3), 300-308. doi: http://dx.doi.org/I0.1080/1465989/.2018.1562576

Kirk, D. S., \& Sampson, R. J. (2013). Juvenile arrest and collateral educational damage in the transition to adulthood. Sociology of education, 86(I), 36-62.

Laursen, B. (2005). Conflict Between Mothers and Adolescents in Single-Mother, Blended, and Two-Biological- Parent Families. Parenting Science and Practice, 5(1), 47-70.

McCord, J. (199I). Family relationships, juvenile delinquency, and adult criminality. Criminology, 29, 397-4I7.

Ministry of Health and Population. (2012). Nepal Adolesecents and Youth Survey 2010/20II. Kathmandu, Nepal.

National Child Right Council. (2019). State of children in Nepal 2019. Government of Nepal Ministry of Women, Children and Senior Citizens, National Child Rights Council.

Olson, D. H., Russell, C. S., \& Sprenkle, D. H. (1983). Circumplex model of marital and family systems: VI. Theoretical update. Family Process, 22(I), 69-83.

Rathinabalan, I., \& Naaraayan, S. A. (2017). Effect of family factors on juvenile delinquency. International Journal of Contemporary Pediatrics, 4(6), 2079. doi: https://doi.org/I0.I8203/2349-329I.ijcp20174735 
Savignac, J. (2009). Families, youth, and delinquency: the state of knowledge, and family-based juvenile delinquency prevention programs(Vol.I). Ottawa, National Crime Preventive centre.

Smith, C., Weiher, A. W., \& Van Kammen, W. B. (1993). Family attachment and delinquency. Urban Delinquency and Substance Abuse. Technical Report. Washington DC.

Stattin, H., \& Kerr, M. (2000). Parental knowledge: A reinterpretation. Child Development, 7/, 1072-1085.

The Act Relating to Children 2075(Nep.). Retrieved from www.lawcommission.gov.np

Thornberry, T. P., \& Krohn, M. D. (2006). Taking stock of delinquency: An overview of findings from contemporary longitudinal studies. Springer Science \& Business Media.

Wright, K.N., \& Wright, K. E. (1994). family life, delinquency, and crime: A policymaker's Guide. Washington, D.C: office of juvenile justice and delinquency prevention.

\section{ANNEX}

\section{Formula of sample size determination}

Taking $95 \%$ confidence level, $5 \%$ margin of the error and $50 \%$ population proportion (since it is unknown), the sample size is computed as:

$$
\mathbf{n}=\frac{Z_{\frac{\alpha}{2}}^{2} p(1-p)}{e^{2}}=\frac{1.96^{2}(0.5)(1-0.5)}{(0.05)^{2}}=384.16=385
$$

Table ANX I. Results of bivariate analysis.

\begin{tabular}{|c|c|c|c|c|c|}
\hline Variable & Category & Control & Case & Total & $\mathrm{P}$-value \\
\hline \multirow[t]{2}{*}{ Family type } & Joint & $66(44 \%)$ & $84(56 \%)$ & 150 & $3.75(0.053)$ \\
\hline & Nuclear & $\begin{array}{l}\text { I I I } \\
(54.4 \%)\end{array}$ & $\begin{array}{l}93 \\
(45.6 \%)\end{array}$ & 204 & \\
\hline \multirow[t]{4}{*}{ Family Structure } & Biological Parents & $\begin{array}{l}160 \\
(90.4 \%)\end{array}$ & $\begin{array}{l}135 \\
(76.3 \%)\end{array}$ & 295 & \multirow[t]{4}{*}{$13.657(0.003)$} \\
\hline & $\begin{array}{l}\text { At least one step- } \\
\text { parent (either } \\
\text { Mother or Father) } \\
\text { in family }\end{array}$ & $5(2.8 \%)$ & $9(5.1 \%)$ & 14 & \\
\hline & Single parent & $12(6.8 \%)$ & $3 \mathrm{I}(17.5 \%)$ & 43 & \\
\hline & No Parent family & $0(0.0 \%)$ & $2(1.1 \%)$ & 2 & \\
\hline \multirow{2}{*}{$\begin{array}{l}\text { With whom the } \\
\text { respondents are } \\
\text { staying }\end{array}$} & Family & $\begin{array}{l}155 \\
(87.6 \%)\end{array}$ & $\begin{array}{l}144 \\
(81.4 \%)\end{array}$ & 299 & \multirow[t]{2}{*}{$2.605(0.107)$} \\
\hline & Others & $22(12.4 \%)$ & $\begin{array}{l}33 \\
(18.6 \%)\end{array}$ & 55 & \\
\hline $\begin{array}{l}\text { Marital number of } \\
\text { Mother }\end{array}$ & Single marriage & $\begin{array}{l}162 \\
(98.8 \%)\end{array}$ & $\begin{array}{l}170 \\
(97.7 \%)\end{array}$ & 332 & $0.564(0.453)$ \\
\hline
\end{tabular}




\begin{tabular}{|c|c|c|c|c|c|}
\hline & Many marriage & $2(1.2 \%)$ & $4(2.3 \%)$ & 6 & \\
\hline \multirow[t]{2}{*}{$\begin{array}{l}\text { Marital number of } \\
\text { father }\end{array}$} & first marriage & $\begin{array}{l}157 \\
(88.7 \%)\end{array}$ & $\begin{array}{l}140 \\
(79.1 \%)\end{array}$ & 297 & \multirow[t]{2}{*}{$6.043(0.014)$} \\
\hline & Many marriage & $20(11.3 \%)$ & $37(20.9 \%)$ & 57 & \\
\hline \multirow[t]{2}{*}{$\begin{array}{l}\text { Marital order of } \\
\text { mother }\end{array}$} & First & $\begin{array}{l}174 \\
(98.3 \%)\end{array}$ & $\begin{array}{l}175 \\
(98.9 \%)\end{array}$ & 349 & \multirow[t]{2}{*}{$0.203(0.652)$} \\
\hline & Second & $3(1.7 \%)$ & $2(1.1 \%)$ & 5 & \\
\hline \multirow[t]{2}{*}{$\begin{array}{l}\text { Marital order of } \\
\text { father }\end{array}$} & First marriage & $169(95.5 \%)$ & $\begin{array}{l}160 \\
(90.4 \%)\end{array}$ & 329 & \multirow[t]{2}{*}{$3.486(0.062)$} \\
\hline & Many marriages & $8(4.5 \%)$ & $17(9.6 \%)$ & 25 & \\
\hline \multirow[t]{2}{*}{ father's age } & $<=50$ & $\begin{array}{l}147 \\
(88.7 \%)\end{array}$ & $\begin{array}{l}127 \\
(79.1 \%)\end{array}$ & 274 & \multirow[t]{2}{*}{$4.620(0.032)$} \\
\hline & $>50$ & $23(11.3 \%)$ & $\begin{array}{l}37 \\
(20.9 \%)\end{array}$ & 60 & \\
\hline \multirow[t]{2}{*}{ Mother's age } & $<=50$ & $162(92.6 \%)$ & $\begin{array}{l}159 \\
(91.9 \%)\end{array}$ & 321 & \multirow[t]{2}{*}{$0.054(0.817)$} \\
\hline & $>50$ & $13(7.4 \%)$ & $14(8.1 \%)$ & 27 & \\
\hline \multirow[t]{4}{*}{$\begin{array}{l}\text { Father's education } \\
\text { level }\end{array}$} & Illiterate & $18(10.5 \%)$ & $\begin{array}{l}45 \\
(27.4 \%)\end{array}$ & 63 & \multirow[t]{4}{*}{$17.082(0.00 I)$} \\
\hline & up to SLC & $\begin{array}{l}128 \\
(74.9 \%)\end{array}$ & $\begin{array}{l}105 \\
(64.0 \%)\end{array}$ & 233 & \\
\hline & intermediate & $12(7.0 \%)$ & $8(4.9 \%)$ & 20 & \\
\hline & Higher education & $13(7.6 \%)$ & $6(3.7 \%)$ & 19 & \\
\hline \multirow[t]{4}{*}{$\begin{array}{l}\text { mother education } \\
\text { level }\end{array}$} & Illiterate & $35(20.3 \%)$ & $\begin{array}{l}80 \\
(46.0 \%)\end{array}$ & 115 & \multirow[t]{4}{*}{$25.904(0.00)$} \\
\hline & up to SLC & $\begin{array}{l}124 \\
(72.1 \%)\end{array}$ & $\begin{array}{l}87 \\
(50.0 \%)\end{array}$ & 211 & \\
\hline & intermediate & $6(3.5 \%)$ & $3(1.7 \%)$ & 9 & \\
\hline & Higher education & $7(4.1 \%)$ & $4(2.3 \%)$ & II & \\
\hline \multirow[t]{4}{*}{ Father's Occupation } & $\begin{array}{l}\text { worked on } \\
\text { agricultural }\end{array}$ & $39(22.0 \%)$ & $\begin{array}{l}52 \\
(29.4 \%)\end{array}$ & 91 & \multirow[t]{4}{*}{ 13.028(0.005) } \\
\hline & $\begin{array}{l}\text { work on sales and } \\
\text { services }\end{array}$ & $\begin{array}{l}117 \\
(66.1 \%)\end{array}$ & $\begin{array}{l}90 \\
(50.8 \%)\end{array}$ & 207 & \\
\hline & $\begin{array}{l}\text { Foreign } \\
\text { employment }\end{array}$ & $12(6.8 \%)$ & $\begin{array}{l}29 \\
(16.4 \%)\end{array}$ & 41 & \\
\hline & Not working & $9(5.1 \%)$ & $6(3.4 \%)$ & 15 & \\
\hline \multirow[t]{4}{*}{ Mother's occupation } & $\begin{array}{l}\text { worked on } \\
\text { agricultural }\end{array}$ & 36 (20.3\%) & $\begin{array}{l}50 \\
(28.2 \%)\end{array}$ & 86 & \multirow[t]{4}{*}{$3.104(0.376)$} \\
\hline & $\begin{array}{l}\text { work on sales and } \\
\text { services }\end{array}$ & $4 \mathrm{I}(23.2 \%)$ & $\begin{array}{l}39 \\
(22.0 \%)\end{array}$ & 80 & \\
\hline & $\begin{array}{l}\text { Foreign } \\
\text { employment }\end{array}$ & $6(3.4 \%)$ & $5(2.8 \%)$ & 11 & \\
\hline & Housewives & $94(53.1 \%)$ & $\begin{array}{l}83 \\
(46.9 \%)\end{array}$ & 177 & \\
\hline \multirow[t]{2}{*}{$\begin{array}{l}\text { Respondent } \\
\text { occupation }\end{array}$} & Student & $\begin{array}{l}176 \\
(99.4 \%)\end{array}$ & $\begin{array}{l}116 \\
(65.5 \%)\end{array}$ & 292 & \multirow[t]{2}{*}{$70.393(0.00)$} \\
\hline & Employee & $I(0.6 \%)$ & $61(34.5) \%$ & 62 & \\
\hline
\end{tabular}


Estimating Nep. J. Stat., Vol. 5, 2021

Impact of factors on juvenile delinquency

\begin{tabular}{|c|c|c|c|c|c|}
\hline \multirow[t]{3}{*}{$\begin{array}{l}\text { Economic condition } \\
\text { of family }\end{array}$} & Low & 66 (37.3\%) & $\begin{array}{l}103 \\
(58.2 \%)\end{array}$ & 169 & \multirow[t]{3}{*}{$17.504(0.00)$} \\
\hline & Medium & $\begin{array}{l}110 \\
(62.1 \%)\end{array}$ & $\begin{array}{l}71 \\
(40.1 \%)\end{array}$ & 181 & \\
\hline & High & I (o.6\%) & $3(1.7 \%)$ & 4 & \\
\hline \multirow[t]{2}{*}{$\begin{array}{l}\text { Smoking status of } \\
\text { the respondent }\end{array}$} & Smoker & $12(6.8 \%)$ & $\begin{array}{l}87 \\
(49.2 \%)\end{array}$ & 99 & \multirow[t]{2}{*}{$78.877(0.00)$} \\
\hline & Non-smoker & $\begin{array}{l}165 \\
(93.2 \%)\end{array}$ & $\begin{array}{l}90 \\
(50.8 \%)\end{array}$ & 255 & \\
\hline \multirow{2}{*}{$\begin{array}{l}\text { Alcohol-consuming } \\
\text { status of the } \\
\text { respondent }\end{array}$} & Alcoholic & $16(9.0 \%)$ & $\begin{array}{l}64 \\
(36.2 \%)\end{array}$ & 80 & \multirow[t]{2}{*}{$37.209(0.00)$} \\
\hline & Non-alcoholic & $\begin{array}{l}161 \\
(91.0 \%)\end{array}$ & $\begin{array}{l}113 \\
(63.8 \%)\end{array}$ & 274 & \\
\hline \multirow[t]{2}{*}{$\begin{array}{l}\text { Smoking status of } \\
\text { parents }\end{array}$} & Smoker & $5 \mathrm{I}(28.8 \%)$ & $\begin{array}{l}86 \\
(48.6 \%) \\
\end{array}$ & 137 & \multirow[t]{2}{*}{ 14.587(0.00) } \\
\hline & Non-Smoker & $\begin{array}{l}126 \\
(71.2 \%) \\
\end{array}$ & $\begin{array}{l}91 \\
(51.4 \%) \\
\end{array}$ & 217 & \\
\hline \multirow[t]{2}{*}{$\begin{array}{l}\text { Alcohol-consuming } \\
\text { status of parents }\end{array}$} & Alcoholic & 91 (5I.4\%) & $\begin{array}{l}95 \\
(53.7 \%)\end{array}$ & 186 & \multirow[t]{2}{*}{$0.181(0.670)$} \\
\hline & Non-alcoholic & $86(48.6 \%)$ & $\begin{array}{l}82 \\
(46.3 \%)\end{array}$ & 168 & \\
\hline \multirow{3}{*}{$\begin{array}{l}\text { Educational } \\
\text { performance of the } \\
\text { respondent }\end{array}$} & Good & 69 (39.0\%) & $\begin{array}{l}67 \\
(37.9 \%)\end{array}$ & 136 & \multirow[t]{3}{*}{$24.926(0.00)$} \\
\hline & Medium & 59 (33.3\%) & $\begin{array}{l}24 \\
(13.6 \%)\end{array}$ & 83 & \\
\hline & Low & 49 (27.7\%) & $\begin{array}{l}86 \\
(48.6 \%)\end{array}$ & 135 & \\
\hline \multirow[t]{3}{*}{$\begin{array}{l}\text { Family relationship } \\
\text { with Neighbor }\end{array}$} & Good & $\begin{array}{l}128 \\
(72.3 \%)\end{array}$ & $\begin{array}{l}76 \\
(42.9 \%) \\
\end{array}$ & 204 & \multirow[t]{3}{*}{$47.726(0.00)$} \\
\hline & Moderate & $43(24.3 \%)$ & $\begin{array}{l}52 \\
(29.4 \%)\end{array}$ & 95 & \\
\hline & Bad & $6(3.4 \%)$ & $\begin{array}{l}49 \\
(27.7 \%)\end{array}$ & 55 & \\
\hline \multirow{2}{*}{$\begin{array}{l}\text { father or mother } \\
\text { punishment when } \\
\text { did something } \\
\text { wrong }\end{array}$} & Yes & $\begin{array}{l}149 \\
(84.2 \%)\end{array}$ & $\begin{array}{l}118 \\
(66.7 \%)\end{array}$ & 267 & \multirow[t]{2}{*}{$14.645(0.00)$} \\
\hline & No & 28 (I5.8\%) & $\begin{array}{l}59 \\
(33.3 \%)\end{array}$ & 87 & \\
\hline \multirow[t]{2}{*}{$\begin{array}{l}\text { Does your father } \\
\text { stay with you? }\end{array}$} & Yes & $\begin{array}{l}131 \\
(74.0 \%)\end{array}$ & $\begin{array}{l}115 \\
(65.0 \%)\end{array}$ & 246 & $3.4 I I(0.065)$ \\
\hline & No & $46(26.0 \%)$ & $\begin{array}{l}62 \\
(35.0 \%)\end{array}$ & 108 & \\
\hline \multirow[t]{3}{*}{$\begin{array}{l}\text { Emotional behavior } \\
\text { of the respondent }\end{array}$} & Aggressive & $36(20.3 \%)$ & $\begin{array}{l}74 \\
(41.8 \%)\end{array}$ & 110 & $19.045(0.00)$ \\
\hline & Humble & 74 (4I.8\%) & $\begin{array}{l}85 \\
(48.0 \%) \\
\end{array}$ & 159 & $1.382(0.240)$ \\
\hline & $\begin{array}{l}\text { Jovial(cheerful and } \\
\text { friendly) }\end{array}$ & $76(42.9 \%)$ & $\begin{array}{l}93 \\
(52.5 \%)\end{array}$ & 169 & $3.272(0.070)$ \\
\hline
\end{tabular}


Table ANX 2. Result of Bivariate analysis.

\begin{tabular}{|c|c|c|c|c|c|c|}
\hline Variables & $\begin{array}{l}\text { Respondent } \\
\text { type }\end{array}$ & Mean & $\begin{array}{l}\text { Std. } \\
\text { Deviation }\end{array}$ & $\begin{array}{l}\text { Std. Error } \\
\text { Mean }\end{array}$ & $\begin{array}{l}\text { t- } \\
\text { value }\end{array}$ & P-value \\
\hline \multirow[t]{2}{*}{ Family size } & Non-Delinquent & 5.7 & 2.33 & 0.18 & \multirow[t]{2}{*}{-1.5} & \multirow[t]{2}{*}{0.14} \\
\hline & Delinquent & 6.1 & 2.88 & 0.22 & & \\
\hline \multirow[t]{2}{*}{ Number of siblings } & Non-Delinquent & 3.0 & 2.13 & 0.23 & \multirow[t]{2}{*}{-2.1} & \multirow[t]{2}{*}{0.04} \\
\hline & Delinquent & 3.7 & 1.82 & 0.20 & & \\
\hline \multirow[t]{2}{*}{ Family Adaptability } & Non-Delinquent & 2.9 & 0.58 & 0.04 & \multirow[t]{2}{*}{7.2} & \multirow[t]{2}{*}{$<0.0001$} \\
\hline & Delinquent & 2.5 & 0.54 & 0.04 & & \\
\hline \multirow[t]{2}{*}{ Family Cohesion } & Non-Delinquent & 4.0 & 0.46 & 0.03 & \multirow[t]{2}{*}{5.7} & \multirow[t]{2}{*}{$<0.0001$} \\
\hline & Delinquent & 3.7 & 0.60 & 0.05 & & \\
\hline \multirow{2}{*}{$\begin{array}{l}\text { Parental } \\
\text { supervision }\end{array}$} & Non-Delinquent & 3.1 & 0.53 & 0.04 & \multirow[t]{2}{*}{2.3} & \multirow[t]{2}{*}{0.03} \\
\hline & Delinquent & 2.9 & 0.91 & 0.07 & & \\
\hline \multirow[t]{2}{*}{ Parental Monitoring } & Non-delinquent & 3.0 & 0.66 & 0.05 & \multirow[t]{2}{*}{2.0} & \multirow[t]{2}{*}{0.04} \\
\hline & Delinquent & 2.8 & 0.92 & 0.07 & & \\
\hline \multirow{2}{*}{$\begin{array}{l}\text { Parental } \\
\text { involvement }\end{array}$} & Non-delinquent & 3.1 & 0.61 & 0.05 & \multirow[t]{2}{*}{5.8} & \multirow[t]{2}{*}{$<0.001$} \\
\hline & delinquent & 2.6 & 0.88 & 0.07 & & \\
\hline \multirow[t]{2}{*}{ Parental attachment } & Non-delinquent & 4.0 & 0.46 & 0.03 & \multirow[t]{2}{*}{10.1} & \multirow[t]{2}{*}{$<0.0001$} \\
\hline & Delinquent & 3.3 & 0.86 & 0.06 & & \\
\hline \multirow[t]{2}{*}{ Family violence } & Non-delinquent & 2.1 & 0.71 & 0.05 & \multirow[t]{2}{*}{-3.5} & \multirow[t]{2}{*}{$<0.0001$} \\
\hline & Delinquent & 2.4 & 0.77 & 0.06 & & \\
\hline
\end{tabular}


Reference to this paper should be made as follows:

Neupane, J., \& Uprety, P. (2021). Impact of family functioning, family violence and other factors on juvenile delinquency. Nep. J. Stat, 5, 79-94. 